\title{
PRACOWNICY ARCHIWÓW PAŃSTWOWYCH \\ W 100-LECIE ICH ISTNIENIA. PRÓBA \\ PORTRETU ZBIOROWEGO
}

\section{Słowa kluczowe}

archiwiści, archiwistyka, archiwa państwowe w Polsce

\section{Keywords}

archivists, archive studies, state archives in Poland

\section{Streszczenie}

Pracownik polskiego archiwum państwowego jest doświadczony, z kilkunastoletnim stażem, przywykły do wykonywania niemal wszystkich zadań realizowanych przez ar-

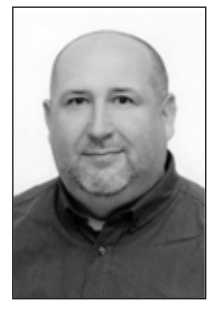

Dariusz Magier, archiwozof, profesor w Instytucie Historii Uniwersytetu Przyrodniczo-Humanistycznego w Siedlcach i kustosz w Archiwum Państwowym w Siedlcach. Zainteresowania naukowe koncentruje na archiwistyce, kancelarii XX w., biurokracji komunistycznej i dziejach najnowszych Podlasia. Autor wielu artykułów naukowych oraz monografii, m.in. System biurokratyczny Polskiej Zjednoczonej Partii Robotniczej w województwie bialskopodlaskim w latach 1975-1990 (Siedlce 2013). E-mail: dmagier@archiwozofia.com ORCID ID: 0000-0001-9367-7448 
chiwum, aczkolwiek nie stroni również od węższej specjalizacji, zwłaszcza w zakresie poszukiwań archiwalnych, opracowania zasobu, udostępniania i informacji naukowej. Jest dobrze wykształcony, co predestynuje go do realizowania klasycznych zadań archiwów. Tak wynika z ankiety przeprowadzonej wśród pracowników archiwów państwowych. Autor na jej podstawie analizuje personel archiwalny, kreśląc portret współczesnego archiwisty państwowej administracji archiwalnej i podejmuje próbę odpowiedzi na pytanie, jakie są obecnie największe problemy archiwów państwowych.

\section{Summary}

Employees of state archives in the 100th anniversary

of their formation. An attempt at group portrayal

Despite the fact that an employee of contemporary state archives has several years of experience in the field and is used to perform almost all tasks within the archives domain, he/she also specializes in specific areas, especially archival research, resource development, files sharing and scientific information. A high level of education enables him/her to accomplish primary tasks of the archives, which has been revealed in a survey conducted among the state archives' personnel. Based on its results, the author draws a portarait of a contemporary state archivist and tries to pinpoint the most serious problems that the state archives face these days.

$\mathbb{W}$ latach 1958-1959 Sekcja Archiwalna przy Związku Zawodowym Pracowników Kultury przeprowadziła ankietę wśród pracowników archiwów państwowych, której wyniki omówione zostały na III Krajowej Naradzie Archiwistów Polskich w październiku 1960 r. Przyniosła ona szczegółowy obraz polskich archiwistów w 40 lat po utworzeniu archiwów państwowych ${ }^{1}$. Okrągła, setna rocznica podpisania przez Naczelnika Państwa dekretu o organizacji archiwów państwowych i opiece nad archiwaliami, który stał się podstawą do budowy i rozwoju współczesnej sieci archiwów państwowych, a także krystalizacji misji państwowej służby archiwalnej w Polsce, skłania do podsumowania kolejnego okresu istnienia państwowej sieci archiwalnej i przeanalizowania podstawowego elementu decydującego o jej funkcjonowaniu - czynnika ludzkiego. Tym samym niniejszy artykuł stanowi próbę sportretowania pracownika współczesnego archiwum państwowego, a niejako przy okazji, poprzez konfrontację z wynikami ankiety sprzed 60 lat (aczkolwiek nie jest to przedmiotem zainteresowania autora niniejszej pracy i będzie analizowane w innym miejscu), daje również

1 Zob. I. Radtke, H. Rappaport, B. Turoń, Wyniki ankiety archiwalnej, „Archeion” 1962 , t. 36 , s. $121-136$. 
możliwość ukazania przeobrażeń w zakresie świadomości, samooceny i kondycji intelektualno-zawodowej pracowników archiwów w Polsce.

Rozważania niniejsze oparte zostały na anonimowej, dobrowolnej internetowej ankiecie przeprowadzonej w dniach od 20 lipca do 17 września 2018 r. na grupie $13,5 \%$ wszystkich zatrudnionych $\mathrm{w}$ archiwach państwowych według stanu na koniec 2017 r. $^{2} \mathrm{~W}$ archiwach państwowych pracuje 1560 osób, z czego $60 \%$ stanowią archiwiści, 16\% pracownicy administracyjni, a $17 \%$ obsługa. Ankieta skierowana była do wszystkich, przy czym założyć trzeba, że możliwość wzięcia w niej udziału mieli tylko ci pracownicy, którzy w związku ze swoją pracą mają dostęp do komputera, co eliminuje na przykład większość pracowników obsługi. Ankietę wypełniły osoby, które wykonują właściwie wszystkie zadania wypełniane przez archiwa. Najwięcej osób zajmuje się realizacją kwerend (49,5\%), udostępnianiem i informacją archiwalną (40\%), opracowaniem (39\%) i nadzorem archiwalnym (26,7\%). Najmniej - digitalizacją (12,9\%), obsługą administracji $(15,7 \%)$ i pracami naukowymi (16,7\%). Należy zaznaczyć, że większość pracowników ma w zakresie swoich obowiązków więcej niż jedno zadanie mimo nominalnej specjalizacji, którą sugeruje struktura archiwów podzielonych na zadaniowe komórki organizacyjne.

Wyspecjalizowanie w wykonywaniu określonych zadań archiwalnych dotyczy przede wszystkim nadzoru - tylko to (i nic więcej) wykonuje 11\% pracowników; kwerend - 10\%; opracowania - 8\%; udostępniania - 5\% i digitalizacji - 3\%.

Pracownik archiwum państwowego jest z reguły doświadczony - ze stażem powyżej 11 lat pracy (powyżej 60\% ogółu pracowników). Udział nowych pracowników jest również wyraźny - ponad 10\%, zauważalna jest jednak rotacja wśród nich w ciągu pierwszych dwóch lat pracy, o czym świadczy stosunkowo mały udział pracowników ze stażem 3-5 lat (nieco ponad 7\%). Wydaje się więc, że ci, którzy przetrwali w archiwum pierwsze trzy lata, częściej już w nim zostają.

Większość pracuje w miastach z populacją powyżej 50 tys., w których znajdują się archiwa regionalne i centralne, jedynie niespełna $20 \%$ - w oddziałach terenowych. Znakomita większość posiada jakąś formę wykształcenia archiwistycznego (studia wyższe na kierunku archiwistyka, studia wyższe ze specjalnością archiwistyczną, archiwistyczne studia podyplomowe, kurs archiwalny). Do braku jakiegokolwiek przygotowania archiwalnego przyznało się niespełna $18 \%$ pracowników archiwów państwowych, jednak myliłby się ten, kto skojarzyłby

2 Pytania i raport z ankiety zob. D. Magier, Wyniki ankiety „Opracowanie $w$ archiwach państwowych AD 2018”, http://archiwozofia.com/single-post/2019/07/17/Wyniki-ankiety-Opracowanie-w-archiwach-pa\%C5\%84stwowych-AD-2018 (dostęp 17.07.2019). 
ich z grupą pracowników administracyjnych. W administracji pracuje zaledwie $22 \%$ z nich, a tylko $8 \%$ zajmuje się digitalizacją. Pozostałe $70 \%$ pracowników nieposiadających archiwistycznego wykształcenia wykonuje różne rodzaje zadań archiwalnych, łącząc przeprowadzanie kwerend (53\%) z udostępnianiem (31\%), opracowaniem (22\%), nadzorem archiwalnym (11\%) i innymi czynnościami. Jak można się było spodziewać, najwięcej pracowników bez wykształcenia archiwistycznego to doświadczeni archiwiści o stażu pracy powyżej 11 lat (53\%). Zaskakuje jednak w tej grupie stosunkowo duża (25\%) liczba młodych pracowników ze stażem 0-2 lata. W czasach szerokiego kształcenia archiwistycznego w Polsce oferowanego przez wiele ośrodków akademickich jest to wynik zastanawiający, zwłaszcza że tylko $22 \%$ tych najmłodszych pracowników archiwów bez archiwistycznego wykształcenia zajmuje się digitalizacją, a zaledwie $11 \%$ pracuje w administracji.

Pracownicy archiwów państwowych z reguły uznają jednak, że kształcenie branżowe dobrze (niemal 30\%) lub przynajmniej częściowo (53\%) przygotowuje do pracy w archiwum państwowym. Ponad 60\% jako główny podręcznik, który im służył, wskazało Archiwistykę H. Robótki, B. Ryszewskiego i A. Tomczaka (Warszawa 1989), na drugim miejscu znalazła się poznańska Metodyka pracy archiwalnej S. Sierpowskiego i S. Nawrockiego (wiele wydań) (28\%), na trzecim Opracowanie i opis archiwaliów H. Robótki (Toruń 2010) (23\%) 3 .

Niezwykle istotnymi pytaniami, które mogą wskazywać również główne problemy współczesnych archiwów, był stosunek pracowników do poszczególnych zadań przez nie realizowanych. Okazuje się, że ulubionymi czynnościami archiwistów (można było wybrać więcej niż jedną odpowiedź) jest realizacja kwerend (43\%), opracowanie zasobu (33\%) oraz udostępnianie i informacja archiwalna, a także popularyzacja (odpowiednio $26 \%$ i $25 \%$ ). Najniższe wskazania pokrywają się z odpowiedziami na pytanie o czynności, których pracownicy nie chcieliby wykonywać. Okazuje się, że najgorszymi zajęciami według polskich archiwistów są nadzór archiwalny (45\% wskazań) i niewiele mu ustępująca digitalizacja (36\%). Przy czym wydaje się, że zupełnie odmienne są powody niechęci archiwistów do tych zadań. Nadzór archiwalny jest niewątpliwie za-

3 10\% wskazało na Metodykę opracowania zasobu archiwalnego ze szczególnym uwzględnieniem akt spraw W. Kwiatkowskiej (Toruń 2010), a spośród innych opracowań wymieniano również: C. Biernat, Problemy archiwistyki wspótczesnej, Warszawa 1977; W. Chorążyczewski, Archiwistyka dla początkujących (wersja 1), Toruń 2014; Kancelaria i archiwum zakładowe, red. E. Borodij (wiele wydań); Dzieje archiwistyki polskiej. Wybór źródet, red. S. Sierpowski, D. Matelski, Poznań 1988; czasopisma o tematyce archiwistycznej, np. „Archeion” i „Archiwista Polski”. 
jęciem trudnym, wymagającym wiedzy z zakresu wielu dziedzin i ciągłego podnoszenia kwalifikacji, a jednocześnie u osób go wykonujących jest pożądana łatwość w nawiązywaniu kontaktów ze światem zewnętrznym, co nie zawsze idzie w parze z typowym wyobrażeniem o pracy archiwisty. Zupełnie odwrotnie jest z digitalizacją, która jest czynnością techniczną, powtarzalną i monotonną, uważaną przez archiwistów za pozostającą poniżej ich wiedzy i możliwości.

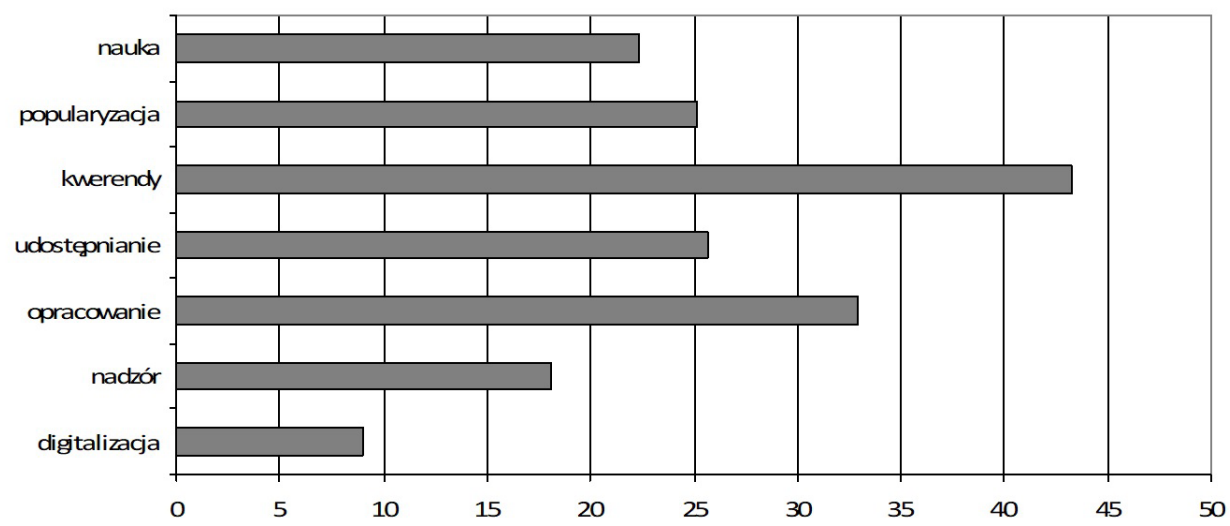

Wykres 1. Ulubione zadania pracowników archiwów państwowych (\%)

Na trzecim miejscu pod względem nielubianych czynności uplasowała się działalność naukowa, która powinna się wiązać ściśle z opracowaniem zasobu. Tymczasem odnotowujemy opracowanie na drugim miejscu wśród ulubionych zadań polskich archiwistów. Może to świadczyć z jednej strony o coraz powszechniejszym odchodzeniu od klasycznej formuły funkcjonowania polskich archiwów państwowych, których źródła tkwią w dziewiętnastowiecznej nauce historycznej, a z drugiej - o zachwianiu równowagi w tradycyjnej dychotomii tkwiącej w archiwum jako urzędzie i placówce naukowej na rzecz urzędowania. Niebezpieczna to droga, która trywializuje archiwistykę stosowaną, odcina archiwa od korzeni, od akademickiej archiwistyki i lokuje archiwistów w morzu urzędników administracji różnego autoramentu. Kryzys ten, który szczególnie widoczny stał się na gruncie działalności naukowej, wydawniczej i opracowania materiałów archiwalnych, przyniósł nie tylko zmiany w praktyce archiwalnej, ale i w świadomości pracowników, zwłaszcza uwzględniwszy pokoleniową wymianę kadry oraz pojawienie się archiwisty nowego typu - absolwenta kierunku archiwistyka, czyli historyka nieoczywistego, zmuszonego do funkcjonowania na gruncie jej nauki pomocniczej. 
W zakresie opracowania kryzys ten jest szczególnie widoczny, gdyż czynność ta, która w przekonaniu wielu pracowników archiwów konstytuuje archiwistę i jego dziejową rolę ( $43 \%$ zajmujących się opracowaniem), była w ostatnich latach rozmyślnie wygaszana ${ }^{4}$.

Opracowaniem zajmuje się mniej niż 40\% zatrudnionych w archiwach państwowych pracowników, ale tylko dla połowy z nich jest to jedyna ich czynność w zakresie obowiązków. Reszta musi łączyć je z prowadzeniem kwerend, udostępnianiem, popularyzacją, nadzorem archiwalnym, obsługą magazynów, prowadzeniem działalności naukowej, sprawami administracyjnymi a nawet rzemieślniczymi (!). W ocenie archiwistów biorących udział w opracowaniu najtrudniejsze są takie jego etapy, jak studia wstępne, rozpoznanie przynależności zespołowej czy systematyzacja akt. Od lat utyskuje się na brak wskazówek metodycznych oraz nikłą pomoc już istniejących. Powszechnie narzekano również na procedurę uznawania zespołów za opracowane oraz niespójność przepisów dotyczących ewidencji, inwentaryzowania oraz wskazówek metodycznych do opracowania poszczególnych rodzajów materiałów archiwalnych, a próba realizacji tych postulatów w postaci uporządkowania przepisów metodycznych i ich dostosowanie do realiów technicznych i społecznych - wprowadzona przepisami w 2018 r. ${ }^{5}$ - nie spotkała się z akceptacją archiwistów (wykres 2), choć zmiany

4 Strategia archiwów państwowych na lata 2010-2020, s. 4, https://www.archiwa. gov.pl/images/docs/Strategia_archiww_pastwowych_na_lata_2010_2020.pdf (dostęp 26.01.2019); W. Stępniak, Koncepcje działania na stanowisku Naczelnego Dyrektora Archiwów Państwowych oraz metody jej realizacji, „Archeion” 2011, t. 112, s. 347-357; tenże, Najważniejsze zmiany $w$ kierunku działalności archiwów państwowych $w$ latach 2011-2013, „Archeion” 2013, t. 114 s. 23-36; W. Woźniak, Koncepcja działania na stanowisku Naczelnego Dyrektora Archiwów Państwowych oraz metody jej realizacji, „Archeion” 2016, t. 117, s. 9-17.

${ }^{5}$ Zarządzenie Nr 7 z 30 stycznia 2018 r. w sprawie ewidencjonowania zasobu archiwalnego w archiwach państwowych, https://www.archiwa.gov.pl/files/zarzadzenia_NDAP/zarz7_2018.pdf (dostęp 2.02.2019); Zarządzenie nr 8 NDAP z 30.01.2018 r. w sprawie inwentaryzacji materiałów archiwalnych oraz sporządzania i zatwierdzania elektronicznych inwentarzy archiwalnych dla zespołów (zbiorów) w archiwach państwowych, https://www.archiwa.gov.pl/files/zarzadzenia_NDAP/zarz8_2018.pdf (dostęp 2.02.2019); Zarządzenie Nr 9 z 30 stycznia 2018 r. w sprawie określenia zakresu i trybu działania komisji metodycznych w archiwach państwowych, https://www.archiwa.gov. pl/files/zarzadzenia_NDAP/zarz9_2018.pdf (dostęp 2.02.2019); Zarządzenie Nr 11 z 30 stycznia 2018 r. w sprawie zasad porządkowania i inwentaryzacji dokumentacji kartograficznej w archiwach państwowych, https://www.archiwa.gov.pl/files/zarzadzenia_NDAP/zarz11_2018.pdf (dostęp 2.02.2019); Zarządzenie Nr 12 z 30 stycznia 2018 r. w sprawie zasad porządkowania i inwentaryzacji materiałów ulotnych w archiwach państwowych, https://www.archiwa.gov.pl/files/zarzadzenia_NDAP/zarz12_2018.pdf 
w funkcjonowaniu komisji metodycznych przyjęto już znacznie lepiej (36\% respondentów poparło je, przy 32\% negatywnych opinii i 32\% braku zdania).

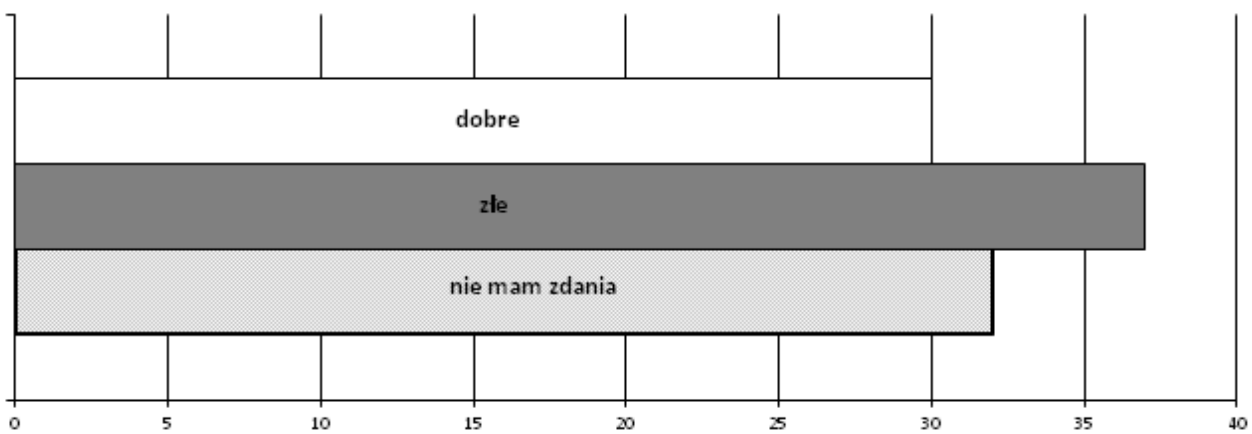

Wykres 2. Zmiany metodyczne wprowadzone w 2018 r. w ocenie archiwistów archiwów państwowych (\%)

Duża grupa osób bez własnego zdania na temat wprowadzonych zmian metodycznych mogłaby świadczyć o tym, że są one zbyt świeże, aby można je było przetestować i ocenić w pracy, zwłaszcza w realiach wstrzymanego faktycznie opracowania. Nie można przy tym stwierdzić, że negatywne nastawienie do zaproponowanych rozwiązań metodycznych to tylko niechęć do nowych rozwiązań ze strony konserwatywnych archiwistów, bo znaczna większość opracowujących zasób uznaje, że zmiany w zakresie metodyki archiwalnej są potrzebne, a wymuszają je realia społeczeństwa informacyjnego, postęp technologiczny czy choćby demokratyzacja dostępu do materiałów archiwalnych. Powodów kryzysu trzeba by szukać więc gdzie indziej.

Wydaje się, że szalę goryczy przelała akcja retrokonwersyjna, a towarzyszące jej swoiste balony próbne w postaci wypowiedzi negujących sens opracowania w obliczu wyzwań ewidencyjnych wprowadziły wielu archiwistów w stan frustracji. Przykład w postaci maksymalnego prymityzowania opracowania do „metadanowania materiałów archiwalnych lub ewentualnego dopracowania już gotowych spisów zdawczo-odbiorczych", do którego nie potrzeba pracy archiwistów, bo może wykonać to firma zewnętrzna, wyartykułowany w prywatnym

(dostęp 2.02.2019); Zarządzenie Nr 13 z 30 stycznia 2018 r. uchylające decyzję w sprawie wprowadzenia wskazówek metodycznych dotyczących uproszczonego opracowania zasobu archiwalnego przechowywanego w archiwach państwowych, https://www.archiwa. gov.pl/files/zarzadzenia_NDAP/zarz13_2018.pdf (dostęp 2.02.2019). 
blogu, ale jednak przez ówczesnego przedstawiciela kadry kierowniczej centralnego organu administracji rządowej w sprawach państwowego zasobu archiwalnego, był już swoistą egzemplifikacją tego kierunku myślenia. Nic dziwnego, że jedyną konkluzją mogło być już tylko stwierdzenie, że „działalność naukowa w archiwum w odniesieniu do opracowania zasobu to niegospodarność i w taki sposób powinno się ją oceniać podczas kontroli finansowych tych jednostek budżetowych"6.

Wszystko to nakłada się na typowe frustracje pracowników archiwów państwowych wskazujących największe, systemowe minusy ich pracy, czyli niskie w stosunku do wiedzy i wykształcenia - pensje (90\% ankietowanych), niedobór zatrudnienia (54\%) i nadmierna biurokracja (35\%). A przecież dochodzą do tego zaskakująco liczne i ciągnące się latami negatywne zjawiska w postaci dysfunkcji biurokratycznych w funkcjonowaniu poszczególnych archiwów, z którymi pracownicy muszą się borykać, co niewątpliwie obniża ich efektywność, takie jak nieprawidłowa organizacja pracy (25\% ankietowanych) czy zła atmosfera (15\%). Wśród wskazywanych przez samych pracowników minusów pracy w archiwum państwowym wymieniano ponadto: społecznie negatywne postrzeganie archiwów, niskie znaczenie instytucji, jego pracowników i wykonywanej przez nich pracy; ciągłe dokładanie zadań bez dodatkowego zatrudnienia lub chociażby podniesienia pensji (przykład digitalizacji); „trudny” dyrektor; akcyjność działania i wciąż zmieniające się priorytety; coraz więcej przypadkowych osób w archiwach; złe warunki pracy; niejasna ścieżka kariery i awansu; niepokrywanie się oczekiwań społecznych odnośnie pracy archiwów z polityką NDAP. Najważniejszym jednak minusem, który został podniesiony w wielu ankietach, a wydaje się wyjątkowo trafny i nieodzowny do sprawnego funkcjonowania całej służby archiwalnej, jest brak jasno sprecyzowanego celu istnienia i funkcjonowania archiwów oraz wieloletniej, konsekwentnej polityki działania. Co oznacza, że koncepcje i priorytety kolejnych naczelnych dyrektorów archiwów państwowych nie są przez ogół pracowników przyjmowane za swoje.

Być może z tego wynika duże, bo niemal dziesięcioprocentowe, grono osób, które nie wiążą swojej przyszłości z archiwum państwowym. Sytuacji nie poprawia również to, że aż 32\% pracowników nie wie, czy chce pozostać w archiwum. Bliższa analiza tych dwóch grup jest tyleż zaskakująca, co bardzo niepokojąca dla polskiej służby archiwalnej. Okazuje się bowiem, że wśród osób, które nie

${ }^{6}$ H. Niestrój, Wynagrodzenie, a praca naukowa w archiwum, http://rotulus.arcaion. $\mathrm{pl} /$ archiwistyka/wynagrodzenie-a-praca-naukowa-w-archiwum (dostęp 2.02.2019). 
wiążą swojej przyszłości z archiwami państwowymi, są głównie pracownicy z ponad jedenastoletnim stażem pracy (25\% osób ze stażem pracy 11-20 lat i 30\% ze stażem pracy ponad 20 lat). W grupie osób wahających się co do pozostania $\mathrm{w}$ archiwum państwowym aż $38 \%$ stanowią pracownicy ze stażem 11-20 lat. I choć w tym zbiorze, tak jak można się było spodziewać, 19\% to nowi pracownicy archiwów (0-2 lata pracy), takie samo podejście wykazują pracownicy związani z archiwami 6-10 lat i aż 16\% pracowników ze stażem ponad 20 lat. Wyniki te dobitnie świadczą, że w funkcjonowaniu archiwów państwowych w ostatnich latach zaszły niepokojące zmiany, które odrzucają najwartościowszych dla każdego pracodawcy, doświadczonych pracowników, na których opiera się działalność całego systemu. Większość z nich wykonuje wiele czynności archiwalnych (68\% wśród osób niewidzących przyszłości w archiwum i 38\% wśród wahających się), ale są tacy i w grupach wyspecjalizowanych na jednym zadaniu, np. odejść chciałoby 10\% digitalizatorów, a spośród niezdecydowanych, czy chcą pracować w państwowej służbie archiwalnej, jest 13\% pracowników nadzoru, 12\% pracowników administracyjnych, 8\% kwerendziarzy, digitalizatorów i opracowujących zasób, 7\% udostępniających akta i 5\% pracowników obsługi. Jak widać, typ wykonywanej pracy raczej nie ma tu znaczenia, skoro problem dotyczy osób, które wykonują zarówno zadania atrakcyjne, jak i mało popularne wśród pracowników archiwów państwowych. Większość chcących pożegnać się ze służbą archiwalną oraz niezdecydowanych pracuje $w$ archiwach regionalnych, gdzie stosunkowo najłatwiej znaleźć lepszą pracę (miasta od 100 tys. do 500 tys. mieszkańców) - odpowiednio 58\% i 45\%, ale zjawisko to nie jest obce również w oddziałach terenowych (miasta do 50 tys. mieszkańców) - 16\% i 18\%.

Na zakończenie spróbujmy nakreślić tytułowy zarys portretu współczesnego pracownika archiwum państwowego: ma doświadczenie, z kilkunastoletnim stażem, przywykły do wykonywania niemal wszystkich zadań realizowanych przez archiwum, aczkolwiek nie stroni również od węższej specjalizacji, zwłaszcza w zakresie poszukiwań archiwalnych, opracowania zasobu, udostępniania i informacji. Branżowo bardzo dobrze wykształcony, co sprawia, że woli realizować klasyczne zadania archiwów, mniej związane z bieżącym życiem prawno-administracyjnym oraz czynnościami czysto technicznymi, takimi jak np. digitalizacja. Odchodzenie archiwów państwowych w ostatnich latach od opracowania zasobu na rzecz ewidencjonowania i retrokonwersji wywołało u archiwisty kryzys tożsamościowy, zaś niskie zarobki, galopująca biurokracja (zamienianie się archiwów w urzędy sensu stricto) i związany z nią niedobór zatrudnienia, a także zacieranie się celu istnienia archiwów, spowodowały 
obniżenie zawodowego morale, co przekłada się na zauważalne symptomy frustracji. Ta ostatnia zaś wywołuje $\mathrm{w}$ archiwiście narastanie niepokojących wątpliwości co do sensu pozostawania w służbie archiwalnej.

\section{Bibliografia}

Magier, Dariusz. „Wyniki ankiety „Opracowanie w archiwach państwowych AD 2018.” Dostęp: 17.07.2019. http://archiwozofia.com/single-post/2019/07/17/Wyniki-ankiety-Opracowanie-w-archiwach-pa\%C5\%84stwowych-AD-2018.

Naczelna Dyrekcja Archiwów Państwowych. „Strategia archiwów państwowych na lata 2010-2020." Dostęp 26.01.2019. https://www.archiwa.gov.pl/images/docs/Strategia_archiww_pastwowych_na_lata_2010_2020.pdf.

Naczelna Dyrekcja Archiwów Państwowych. „Zarządzenie Nr 7 z 30.01.2018 r. w sprawie ewidencjonowania zasobu archiwalnego w archiwach państwowych.” Dostęp: 2.02.2019. https://www.archiwa.gov.pl/files/zarzadzenia_NDAP/zarz7_2018.pdf.

Naczelna Dyrekcja Archiwów Państwowych. „Zarządzenie Nr 8 NDAP z 30.01.2018 r. w sprawie inwentaryzacji materiałów archiwalnych oraz sporządzania i zatwierdzania elektronicznych inwentarzy archiwalnych dla zespołów (zbiorów) w archiwach państwowych.” Dostęp 02.02.2019. https://www.archiwa.gov.pl/files/zarzadzenia_NDAP/zarz8_2018.pdf.

Naczelna Dyrekcja Archiwów Państwowych. „Zarządzenie Nr 9 z 30.01.2018 r. w sprawie określenia zakresu i trybu działania komisji metodycznych w archiwach państwowych." Dostęp 02.02.2019. https://www.archiwa.gov.pl/files/zarzadzenia_NDAP/ zarz9_2018.pdf.

Naczelna Dyrekcja Archiwów Państwowych. „Zarządzenie Nr 11 z 30.01.2018 r. w sprawie zasad porządkowania i inwentaryzacji dokumentacji kartograficznej w archiwach państwowych." Dostęp 02.02.2019. https://www.archiwa.gov.pl/files/zarzadzenia_NDAP/zarz11_2018.pdf.

Naczelna Dyrekcja Archiwów Państwowych. „Zarządzenie Nr 12 z 30.01.2018 r. w sprawie zasad porządkowania i inwentaryzacji materiałów ulotnych w archiwach państwowych.” Dostęp 02.02.2019. https://www.archiwa.gov.pl/files/zarzadzenia_NDAP/ zarz12_2018.pdf.

Naczelna Dyrekcja Archiwów Państwowych. „Zarządzenie Nr 13 z 30.01.2018 r. uchylające decyzję w sprawie wprowadzenia wskazówek metodycznych dotyczących uproszczonego opracowania zasobu archiwalnego przechowywanego w archiwach państwowych." Dostęp 02.02.2019. https://www.archiwa.gov.pl/files/zarzadzenia_NDAP/zarz13_2018.pdf.

Niestrój, Henryk. „Wynagrodzenie, a praca naukowa w archiwum.” Dostęp 02.02.2019. http://rotulus.arcaion.pl/archiwistyka/wynagrodzenie-a-praca-naukowa-w-archiwum.

Radtke, Irena, Herman Rappaport, i Bronisław Turoń. „Wyniki ankiety archiwalnej.” Archeion 36 (1962): 121-136. 
Stępniak, Władysław. „Koncepcje działania na stanowisku Naczelnego Dyrektora Archiwów Państwowych oraz metody jej realizacji." Archeion 112 (2011): 347-357.

Stępniak, Władysław. „Najważniejsze zmiany w kierunku działalności archiwów państwowych w latach 2011-2013." Archeion 114 (2013): 23-36.

Woźniak, Wojciech. „Koncepcja działania na stanowisku Naczelnego Dyrektora Archiwów Państwowych oraz metody jej realizacji.” Archeion 117 (2016): 9-17. 
